\title{
Effects of carbohydrate intake on time to exhaustion and anaerobic contribution during supramaximal exercise
}

\author{
Efeito da ingestão de carboidrato sobre o tempo \\ de exaustão e contribuição anaeróbia \\ durante exercício supramáximo.
}

Victor José BASTOS-SILVA ${ }^{1}$

Sara Kely LEARSI ${ }^{2}$

Alan de Albuquerque MELO'

Adriano Eduardo LIMA-SILVA²

Gustavo Gomes de ARAUJO'1

\section{A B S T R A C T}

\section{Objective}

This study evaluated the effect of carbohydrate intake on time to exhaustion and anaerobic contribution during supramaximal exercise on a cycle ergometer.

\section{Methods}

The sample comprised ten participants with a mean age of $23.9 \pm 2.5$ years, mean body mass of $75.1 \pm 12.3 \mathrm{~kg}$, mean height of $170.0 \pm 1.0 \mathrm{~cm}$, and mean body fat of $11.3 \pm 5.2 \%$. The participants underwent an incremental test to determine maximal oxygen uptake and maximum power output, and two supramaximal tests with a constant load of $110 \%$ of the maximum power output to exhaustion. Thirty minutes before the supramaximal tests the participants consumed carbohydrates $\left(2 \mathrm{~g} \mathrm{~kg}^{-1}\right)$ or placebo.

\section{Results}

The times to exhaustion of carbohydrate and placebo did not differ (carbohydrate: $170.7 \pm 44$.6s; placebo: 156.1 $\pm 26.7 \mathrm{~s}, p=0.17$; effect size $=0.39$ ). Similarly, the anaerobic contributions of the two treatments did not differ (carbohydrate: $3.0 \pm 0.9$ L; placebo: $2.7 \pm 1.1 \mathrm{~L}, p=0.23$; effect size=0.29).

\footnotetext{
$\overline{1}$ Universidade Federal de Alagoas, Departamento de Educação Física, Programa de Pós-Graduação em Nutrição, Grupo de Pesquisa em Ciências Aplicadas ao Esporte. Av. Lourival Melo Mota, s/n., Tabuleiro dos Martins, Maceió, AL, Brasil. Correspondência para/Correspondence to: GG ARAUJO.E-mail: <gusta_ef@yahoo.com.br>.

2 Universidade Federal de Pernambuco, Centro Acadêmico de Vitória, Grupo de Pesquisa em Ciências do Esporte. Vitória de Santo Antão, PE, Brasil.
} 


\section{Conclusion}

Carbohydrate intake was not capable of increasing time to exhaustion and anaerobic contribution in physically active men cycling at $110 \%$ of maximum power output.

Keywords: Anaerobic capacity. Athletic performance. Fatigue. Sports nutritional sciences.

\section{R E S U M O}

\section{Objetivo}

Este estudo foi conduzido com o intuito de verificar o efeito da ingestão de carboidrato sobre o tempo de exaustão e a contribuição anaeróbia durante o exercício supramáximo em uma bicicleta ergométrica.

\section{Métodos}

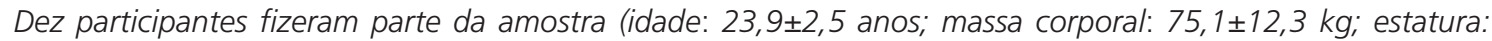
$170,0 \pm 1,0 \mathrm{~cm}$; gordura corporal: 11,3 $\pm 5,2 \%$ ). Todos realizaram um teste incremental para determinar o consumo máximo de oxigênio e a potência máxima e dois testes supramáximos com carga constante de $110 \%$ da potência máxima até a exaustão. Os participantes ingeriram carboidrato (2 $\left.\mathrm{g} \cdot \mathrm{kg}^{-1}\right)$ ou placebo 30 minutos antes dos testes supramáximos.

\section{Resultados}

Não houve diferença significativa no tempo de exaustão entre carboidrato e placebo (carboidrato: 170,7士44,6s; placebo: 156,1 26,7s, $p=0,17$; effect size=0,39). De forma similar, não houve diferença significativa na

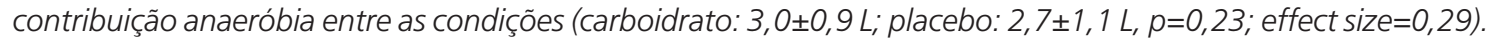

\section{Conclusão}

A ingestão de carboidrato não foi capaz de aumentar o tempo até a exaustão e a contribuição anaeróbia em exercícios à $110 \%$ da potência máxima em homens fisicamente ativos.

Palavras-chave: Capacidade anaeróbia. Desempenho atlético. Fadiga. Ciência da nutrição e do esporte.

\section{INTRODUCTION}

Some studies have found that carbohydrate intake before prolonged exercise (>60 $\mathrm{min}$ ) can improve performance ${ }^{1,2}$. Recently, it has been reported that the intake of a carbohydrate drink 30 min before high-intensity exercise at $90 \%$ of peak power output improved performance by $17 \%$ compared with placebo ${ }^{3}$. Although these authors speculated that pre-exercise blood glucose enhance can increase glucose absorption and oxidation during skeletal muscle contraction due to higher activity of the pyruvate dehydrogenase complex, alactic and lactic anaerobic metabolisms were not measured during the tests. Bergström \& Hultman ${ }^{4}$ found that muscle glycogen is not completely depleted during high-intensity exercises, so it is not a limiting factor for exercise performance. Moreover, higher availability of muscle glycogen after a high-carbohydrate meal has no effect on performance during highintensity exercise ${ }^{5,6}$.

A plausible explanation for better performance in high-intensity exercises after carbohydrate intake is higher neuromuscular activation, which may lead to higher recruitment of type IIx fibers ${ }^{7}$ and concomitantly increase anaerobic glycolysis ${ }^{8}$. Higher neuromuscular activation may be explained by activation of the cerebral cortex due to oral carbohydrate sensing, intermediated by the carbohydrate receptors in the mouth ${ }^{9}$. Oral carbohydrate sensing may increase neuromuscular activation ${ }^{10}$ and activation of brain areas responsible for motivation, including the frontal operculum/insula, and orbitofrontal cortex and striatum ${ }^{11,12}$. However, it is not entirely known whether these ergogenic effects can be extended to short-term supramaximal exercises ( 3 min) and improve anaerobic contribution ${ }^{13-16}$. 
Therefore, the objective of this study was to analyze the effect of carbohydrate intake on time to exhaustion and anaerobic contribution during supramaximal exercise. Carbohydrate intake may improve performance, that is, increase time to exhaustion, by promoting higher neuromuscular recruitment ${ }^{10}$ secondary to oral carbohydrate sensing ${ }^{9}$, thereby generating higher anaerobic contribution.

\section{METHOD S}

The study included ten volunteers with a mean age of $23.9 \pm 2.5$ years, mean body mass of $75.1 \pm 12.3 \mathrm{~kg}$, mean height of $170.0 \pm 1.0 \mathrm{~cm}$, mean body fat of $11.3 \pm 5.2 \%$, and mean $\mathrm{VO}_{2 \text { máx }}$ of $42.1 \pm 5.2 \mathrm{~mL} \cdot \mathrm{kg}^{-1} \cdot \mathrm{min}^{-1}$. All volunteers were healthy and physically active men who performed at least 150 min of physical activity per week. Before enrollment, the participants were fully informed in writing and verbally about the study purpose and risks. Each participant signed an informed consent form before starting the tests. The experimental protocol complied with the Declaration of Helsinki 2008 and was approved by the local Universidade Federal de Alagoas (Federal University of Alagoas) Research Ethics Committee under protocol no 1420/12.

This is a blind, counterbalanced, crossover study. The participants performed three experimental sessions with a minimum interval of $72 \mathrm{~h}$. During the first visit, anthropometric parameters were measured and an incremental test was conducted to determine maximal oxygen uptake $\left(\mathrm{VO}_{2 \max }\right)$ and maximal power output. During the second and third visits, a supramaximal test at $110 \%$ of maximal power output was conducted to voluntary exhaustion after carbohydrate or placebo interventions. All tests were conducted at the same time of day, two hours after the last meal ${ }^{17}$. The participants were instructed to replicate their food intake $24 \mathrm{~h}$ before each experimental test, and before each test the researchers verified whether the recommendations had been followed. The participants were instructed to avoid exhaustive exercise, and alcohol and caffeine intakes in the $48 \mathrm{~h}$ that preceded each experimental test.

Thirty minutes before the test, the participants consumed $200 \mathrm{~mL}$ of water with 2 g. $\mathrm{kg}^{-1}$ of body weight of maltodextrin (carbohydrate) or juice without carbohydrate (placebo) but with the same flavor, aroma, and texture. The participants then rested until assessment.

The body mass of the participants was measured by a scale with an accuracy of $0.1 \mathrm{~kg}$. Height was measured by a stadiometer with an accuracy of $0.1 \mathrm{~cm}$. Skinfold thicknesses (thorax, abdominal, and thigh) were measured by a Lange adipometer in a scale of 0 to $60 \mathrm{~mm}$, resolution of one millimeter, and a spring with constant pressure of $10 \mathrm{~g} / \mathrm{mm}^{2}$. Body density was predicted by the generalized equation proposed by Jackson \& Pollock ${ }^{18}$, and body fat was estimated by the equation proposed by Siri' ${ }^{19}$.

The incremental test was performed on an electromagnetically braked cycle ergometer (Ergo Fit 167, Ergo-Fit GmbH \& Co., Pirmasens, Germany). Saddle height was adjusted for each participant allowing almost full extension of the leg during each cycle. These conditions were repeated for all experimental sessions. After a warmup of 3 min at $30 \mathrm{~W}$, the power was increased to $30 \mathrm{~W} \cdot \mathrm{min}^{-1}$, and cadence was maintained between 60 and $70 \mathrm{rpm}$ until voluntary exhaustion, which was defined as the inability to maintain a minimal cadence of $60 \mathrm{rpm}$. The participants were cheered to cycle as long as possible.

Oxygen uptake $\left(\mathrm{VO}_{2}\right)$ was measured at each breath by a gas analyzer (Quark, Cosmed, Rome, Italy) and assessed at roughly every 30s. The device was calibrated as instructed by the manufacturer, using room air, a gas containing $20.9 \%$ of $\mathrm{O}_{2}$ and $5 \%$ of $\mathrm{CO}_{2}$, and a $3 \mathrm{~L}$ syringe. $\mathrm{VO}_{2 \text { máx }}$ was determined when two or more of the following criteria were met: $\mathrm{V}_{2} \mathrm{O}_{2}$ increase smaller than $2.1 \mathrm{~mL} \cdot \mathrm{kg}^{-1} \cdot \mathrm{min}^{-1}$ on two consecutive stages, a respiratory exchange ratio higher than 1.1, and $\pm 10 \mathrm{bpm}$ of the maximum recommended heart 
rate for the participant's age ${ }^{20}$. The maximal power output was based on the $\mathrm{VO}_{2 \text { max }}$ stage.

A supramaximal test was conducted at $110 \%$ of the maximal power output. This intensity was chosen because of the study conducted by Weber \& Schneider ${ }^{21}$ to estimate maximal anaerobic contribution using the maximal accumulated oxygen deficit proposed by Bertuzzi et al. ${ }^{22}$.

The participants remained inactive on the cycle ergometer for five min to determine baseline $\mathrm{VO}_{2}$. The participants then warmed up for four $\min$ at $30 \mathrm{~W}$. Next, the power was adjusted to $110 \%$ of the maximal power output. The participants were instructed to maintain a cadence of 60 to $70 \mathrm{rpm}$. The test ended when cadence fell below $60 \mathrm{rpm}$ for more than $5 \mathrm{~s}$ or for a fourth time. The participants were again cheered during the whole test. The peak oxygen uptake $\left(\mathrm{VO}_{2 \text { peak }}\right)$ was defined as the mean of the last 30s of the test. Blood samples were collected from the ear lobe before and immediately, $3 \mathrm{~min}$, and $5 \mathrm{~min}$ after the exercise. Peak blood lactate ([La- $\left.]_{\text {peak }}\right)$ was defined as the highest value obtained after the test.

Anaerobic contribution was calculated as recommended by Bertuzzi et al. ${ }^{22}$. In summary, the breath-by-breath of the $\mathrm{VO}_{2}$ off-transient response was adjusted by a two-exponential model, and the area under the curve of the first exponential was calculated to estimate the alactic contribution (Origin 6.0, Microcal, Massachusetts, USA). The difference between $\left[\mathrm{La}^{-}\right]_{\text {peak }}$ and $\left[\mathrm{La}^{-}\right]_{\text {rest }}$ during the supramaximal test was expressed as a difference $\left(\left[\mathrm{La}^{-}\right]_{\text {net }}\right)$ and converted to oxygen uptake using the equation proposed by $\mathrm{Di}$ Prampero \& Ferretti ${ }^{23}$, that is, $1 \mathrm{mmoLL}^{-1}\left[\mathrm{La}^{-}\right]_{\text {net }}$ is equal to $3 \mathrm{~mL} \mathrm{O} \cdot \mathrm{kg}^{-1}$ of body weight to estimate lactic contribution. Total anaerobic contribution was obtained by adding the alactic and lactic contributions. The values were then divided by one thousand to convert milliliters to liters.

The Shapiro-Wilk test analyzed data distribution. The data were expressed as mean and standard deviation. The paired Student's $t$-test compared the differences between the carbohydrate and placebo interventions. The significance level was set at $5 \%(p<0.05)$. All statistical calculations were performed by the software Statistical Package for the Social Sciences (SPSS Inc., Chicago, Illinois, United States) version 17.0 for Windows.

The effect size was calculated for all carbohydrate and placebo variables. The thresholds for the small, moderate, and large effects were $0.20,0.50$, and 0.80 , respectively. The effect size was determined by the formula: (mean1 - mean2) / grouped standard deviation ${ }^{24}$.

\section{R E S U L T S}

Time to exhaustion was similar for the carbohydrate and placebo interventions $(170.7 \pm 44.6 s$ and $156.1 \pm 26.7 s$, respectively; $p=0.17$; effect size $=0.39$ ). Peak blood lactate ( $p=0.06$; effect size $=0.57)$, alactic $(p=0.13$; effect size $=0.19)$ and lactic $(p=0.14$; effect size $=0.45)$ energy systems, and $\mathrm{VO}_{\text {2peak }}$ (carbohydrate: $47.2 \pm 6.7 \mathrm{~mL} \cdot \mathrm{kg}^{-1} \cdot \mathrm{min}^{-1}$; placebo: $47.3 \pm 6.9$ $\mathrm{mL} \cdot \mathrm{kg}^{-1} \cdot \mathrm{min}^{-1}, p=0.96$; effect size $=0.01$ ) of the carbohydrate and placebo interventions also did not differ (Table 1). Consequently, the total anaerobic contributions of the two interventions were similar ( $p=0.23$; effect size=0.29; Figure 1).

Table 1. Peak lactate, and percentage lactic and alactic contributions.

\begin{tabular}{|c|c|c|c|c|c|c|}
\hline & \multicolumn{2}{|c|}{ Peak lactate (mmol) } & \multicolumn{2}{|c|}{$\%$ Lactic contribution } & \multicolumn{2}{|c|}{$\%$ Alactic contribution } \\
\hline & Placebo & Carbohydrate & Placebo & Carbohydrate & Placebo & Carbohydrate \\
\hline Mean & 7.9 & 10.1 & 41.6 & 58.4 & 53.9 & 46.1 \\
\hline Standard Deviation & 3.9 & 3.4 & 13.4 & 13.4 & 7.5 & 7.5 \\
\hline
\end{tabular}




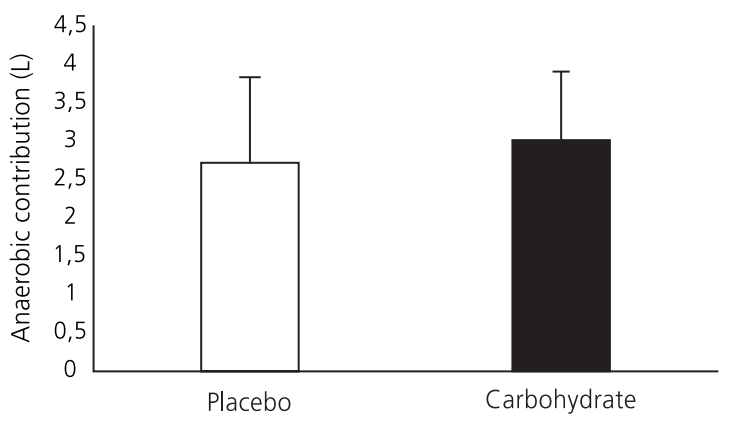

Figure 1. Total anaerobic contribuition in the placebo and carbohydrate intervention.

\section{DISCUSSION}

Apparently this is the first study that investigated the effects of pre-exercise carbohydrate intake on time to exhaustion and anaerobic contribution during supramaximal exercise. The study results encourage interesting considerations about the ergogenic effects of carbohydrate intake, indicating that such intake does not seem capable of increasing time to exhaustion and anaerobic contribution during supramaximal exercise in physically active men.

Carbohydrate supplementation can delay fatigue onset and concomitantly, increase time to exhaustion during exercises with intensities ranging from $70 \%$ to $90 \%$ of peak power $r^{1-3,25,26}$. However, the effects of pre-exercise carbohydrate intake on supramaximal exercise are not well known. The study results suggest that time to exhaustion does not improve significantly during an exercise at $110 \%$ of maximal power output. Some pieces of evidence suggest that pre-exercise carbohydrate intake increases performance during high-intensity exercise. Galloway et al. ${ }^{3}$ found an increase in time to exhaustion at $90 \%$ of peak power output when their subjects ingested $500 \mathrm{~mL}$ of a drink containing carbohydrates and electrolytes (6.4\% carbohydrate, 32 g) $30 \mathrm{~min}$ before exercise compared with a placebo with same flavor and color ( $0.1 \%$ carbohydrate). The length of the postprandial period may explain this discrepancy. Galloway et al. ${ }^{3}$ used an overnight fast (>10h), which may lead to considerable depletion of hepatic glycogen, so an exogenous supply of carbohydrate helps to avoid glucose regulation failure and hypoglycemia during exercise ${ }^{1}$. However, the present study conducted the tests $2 \mathrm{~h}$ after the last meal, simulating conditions more alike those normally observed in sports and training programs ${ }^{17}$.

Additionally, some studies found that baseline muscle glycogen content does not affect muscle glycogen breakdown during high-intensity exercises. This may explain why carbohydrate intake and a high-carbohydrate diet do not affect time to exhaustion and anaerobic contribution during supramaximal exercise $e^{6,27,28}$. In this context, the study data reinforce the abovementioned results, showing that, like higher muscle glycogen content, an exogenous carbohydrate source has no positive effect on performance and anaerobic contribution during supramaximal exercise ${ }^{5}$. Although performance and anaerobic contribution did not change significantly, peak blood lactate had a moderate effect size (0.57), possibly because of higher pyruvate dehydrogenase complex activity, as reported by Galloway et al. ${ }^{3}$.

With respect to the ergogenic effect of oral carbohydrate sensing on performance, most studies have reported improvements during exercises at intensities below $\mathrm{VO}_{2 \max }$ $\left(\sim 75 \%\right.$ ofVO $\left._{2 \max }\right)$. Studies using anaerobic tasks ${ }^{29}$ and resistance training ${ }^{30}$ did not find a positive effect of oral carbohydrate sensing on performance, possibly because exercises at submaximal intensities recruit only some motor units while supramaximal exercises can recruit nearly all motor units ${ }^{31}$. This fact may minimize any oral carbohydrate sensing effect during supramaximal exercises. Hence, as practical application, the present study reinforces the hypothesis that carbohydrate intake before short-term highintensity exercises does not seem to be an effective strategy to improve performance.

One of the possible study limitations is the time between tests. The initial proposal was of a minimum interval of 72 hours. However, some 
subjects performed the second supramaximal test after a $96 \mathrm{~h}$ recovery period. Another possible limitation may be the physical fitness of our sample. More physically fit subjects could be more sensitive to the study effects.

\section{CONCLUSION}

Carbohydrate intake did not increase time to exhaustion or anaerobic contribution during supramaximal exercise in physically active men.

\section{ACKNOWLEDGMENTS}

We thank the Laboratory of Physical Fitness, Performance, and Health of the Federal University of Alagoas and the sponsor Research Support Foundation of the State of Alagoas.

\section{CONTRIBUTORS}

VB SILVA and SK LEARSI participated in the elaboration of the experimental design, data collection, tabulation, discussion and writing of the manuscript. AA MELO participated in data collection, data discussion and writing of the manuscript. AE LIMA-SILVA and GG ARAUJO participated in the preparation of the research project, in the elaboration of the experimental design, data discussion as well as writing and correction of the manuscript.

\section{REFERENCES}

1. Coyle EF, Coggan AR, Hemmert MK, Ivy JL. Muscle glycogen utilization during prolonged strenuous exercise when fed carbohydrate. J Appl Physiol. 1986; 61(1):165-72.

2. Angus DJ, Hargreaves M, Dancey J, Febbraio MA. Effect of carbohydrate or carbohydrate plus medium-chain triglyceride ingestion on cycling time trial performance. J Appl Physiol. 2000; 88(1):113-9.

3. Galloway SD, Lott MJ, Toulouse LC. Preexercise carbohydrate feeding and high-intensity exercise capacity: Effects of timing of intake and carbohydrate concentration. Int I Sport Nutr Exerc Metab. 2014; 24(3):258-66. http://dx.doi.org/10. 1123/ijsnem.2013-0119
4. Bergström J, Hultman E. A study of the glycogen metabolism during exercise in man. Scand J Clin Lab Invest. 1967; 19(3):218-28.

5. Hargreaves M, Finn JP, Withers RT, Halbert JA, Scroop GC, Mackay M, et al. Effect of muscle glycogen availability on maximal exercise performance. Eur J Appl Physiol Occup Physiol. 1997; 75(2):188-92.

6. Lima-Silva AE, Pires FO, Bertuzzi R, Silva-Cavalcante $M D$, Oliveira RS, Kiss MA, et al. Effects of a low- or a high-carbohydrate diet on performance, energy system contribution, and metabolic responses during supramaximal exercise. Appl Physiol Nutr Metab. 2013; 38(9):928-34. http://dx.doi.org/10. 1139/apnm-2012-0467

7. Henneman E, Somjen G, Carpenter DO. Functional significance of cell size in spinal motoneurons. J Neurophysiol. 1965; 28:560-80.

8. Greising SM, Gransee HM, Mantilla CB, Sieck GC. Systems biology of skeletal muscle: Fiber type as an organizing principle. Wiley Interdiscip Rev Syst Biol Med. 2012; 4(5):457-73. http://dx.doi.org/10. 1002/wsbm.1184

9. Rollo I, Williams C, Nevill M. Influence of ingesting versus mouth rinsing a carbohydrate solution during a 1-h run. Med Sci Sports Exerc. 2011; 43(3):468-75. http://dx.doi.org/10.1249/MSS.0b0 $13 \mathrm{e} 3181 \mathrm{f1cda3}$

10. Gant N, Stinear CM, Byblow WD. Carbohydrate in the mouth immediately facilitates motor output. Brain Res. 2010; 1350:151-8. http://dx.doi.org/10. 1016/j.brainres.2010.04.004

11. Chambers ES, Bridge MW, Jones DA. Carbohydrate sensing in the human mouth: Effects on exercise performance and brain activity. J Physiol. 2009; 587(8):1779-94. http://dx.doi.org/10.1113/ jphysiol.2008.164285

12. Turner CE, Byblow WD, Stinear CM, Gant N. Carbohydrate in the mouth enhances activation of brain circuitry involved in motor performance and sensory perception. Appetite. 2014; 80:212-9. http://dx.doi.org/10.1016/j.appet.2014.05.020

13. Chong E, Guelfi KJ, Fournier PA. Effect of a carbohydrate mouth rinse on maximal sprint performance in competitive male cyclists. J Sci Med Sport. 2011; 14(2):162-7. http://dx.doi.org/10.10 16/j.jsams.2010.08.003

14. Beaven CM, Maulder P, Pooley A, Kilduff L, Cook C. Effects of caffeine and carbohydrate mouth rinses on repeated sprint performance. Appl Physiol Nutr Metab. 2013; 38(6):633-7. http://dx.doi.org/ 10.1139/apnm-2012-0333

15. Chong E, Guelfi KJ, Fournier PA. Combined glucose ingestion and mouth rinsing improves sprint cycling performance. Int J Sport Nutr Exerc Metab. 2014; 
24(6):605-12. http://dx.doi.org/10.1123/ijsnem. 2013-0097

16. Phillips SM, Findlay S, Kavaliauskas M, Grant MC. The influence of serial carbohydrate mouth rinsing on power output during a cycle sprint. J Sports Sci Med. 2014; 13(2):252-8.

17. Lane SC, Bird SR, Burke LM, Hawley JA. Effect of a carbohydrate mouth rinse on simulated cycling time-trial performance commenced in a fed or fasted state. Appl Physiol Nutr Metab. 2013; 38(2):134-9. http://dx.doi.org/10.1139/apnm-20 $12-0300$

18. Jackson AS, Pollock ML. Practical assessment of body composition. Physician Sportsmed, 1985; 13(5):76-90.

19. Siri WE. Body composition from fluids spaces and density: Analyses of methods. In: Brozek J \& Henschel A, editors. Techniques for measuring body composition. Washington (DC): National Academy of Science and Natural Resource Council; 1961.

20. Howley ET, Bassett DR Jr, Welch HG. Criteria for maximal oxygen uptake: Review and commentary. Med Sci Sports Exerc. 1995; 27(9):1292-301.

21. Weber CL, Schneider DA. Reliability of MAOD measured at $110 \%$ and $120 \%$ of peak oxygen uptake for cycling. Med Sci Sports Exerc. 2001; 33(6):1056-9.

22. Bertuzzi RC, Franchini E, Ugrinowitsch C, Kokubun E, Lima-Silva AE, Pires FO, et al. Predicting MAOD using only a supramaximal exhaustive test. Int J Sports Med. 2010; 31(7):477-81. http://dx.doi.org/10. 1055/s-0030-1253375

23. Di Prampero PE, Ferretti G. The energetics of anaerobic muscle metabolism: A reappraisal of older and recent concepts. Respir Physiol. 1999; 118(2-3):103-15.
24. Cohen J. Statistical power analysis for the behavioral sciences. 2a ed. Hillsdale: Erlbaum; 1988.

25. Anantaraman R, Carmines AA, Gaesser GA, Weltman A. Effects of carbohydrate supplementation on performance during 1 hour of high-intensity exercise. Int J Sports Med. 1995; 16(7):461-5.

26. Jeukendrup A, Brouns $F$, Wagenmakers AJ, Saris WH. Carbohydrate-electrolyte feedings improve 1 h time trial cycling performance. Int J Sports Med. 1997; 18(2):125-9.

27. Bangsbo J, Graham TE, Kiens B, Saltin B. Elevated muscle glycogen and anaerobic energy production during exhaustive exercise in man. J Physiol. 1992; 451(1):205-27.

28. Ren JM, Broberg S, Sahlin K, Hultman E. Influence of reduced glycogen level on glycogenolysis during short-term stimulation in man. Acta Physiol Scand. 1990; 139(3):467-74.

29. Dorling JL, Earnest CP. Effect of carbohydrate mouth rinsing on multiple sprint performance. J Int Soc Sports Nutr. 2013; 10(1):41. http://dx.doi.org/10. 1186/1550-2783-10-41

30. Painelli VS, Roschel H, Gualano B, Del-Favero S, Benatti FB, Ugrinowitsch $C$, et al. The effect of carbohydrate mouth rinse on maximal strength and strength endurance. Eur J Appl Physiol. 2011; 111(9):2381-6. http://dx.doi.org/10.1007/s00421-01 1-1865-8

31. Hunter AM, St Clair Gibson A, Lambert MI, Nobbs $L$, Noakes TD. Effects of supramaximal exercise on the electromyographic signal. Br J Sports Med. 2003; 37(4):296-9.
Received: November 16, 2015 Final version: March 2, 2016 Approved: May 11, 2016 
